\title{
Perceived University Support: How Does It Build the Entrepreneurial Intention? A Case from Indonesia
}

\author{
Ririn Alfianti ${ }^{1, *}$, Kemal Budi Mulyono ${ }^{1}$, Firda Nurhidayati ${ }^{1}$ \\ ${ }^{1}$ Faculty of Economics, Universitas Negeri Semarang \\ ${ }^{*}$ Corresponding author. Email: sonmuly@mail.unnes.ac.id
}

\begin{abstract}
The growing number of new entrepreneurs is an urgent target that must be met by universities. However, support from universities to create new entrepreneurs is often less than optimal. Therefore, this study explores and tests the extent to which student's perceived university support can increase the impact of entrepreneurial literacy on student's intention to become entrepreneurs. By using primary data obtained from studentpreneur who are members of the entrepreneurial community HIPMI PT (Association of Young Entrepreneurs Indonesia-Universities) in Semarang through a questionnaire with the number 168. Through the Warp-PLS SEM inferential statistical technique, the results showed that perceived university support was significant in moderating the effect of entrepreneurial literacy on entrepreneurial intention. It has practical implications for the priority of university academic and student affairs policies to focus on all forms of activities or programs that encourage and support student entrepreneurial activities in the form of a community, as well as the need for seriousness in supporting student business incubators.
\end{abstract}

\section{Keywords: Entrepreneurial Literacy, Perceived University Support, Entrepreneurial Intention}

\section{INTRODUCTION}

Along with the increase in population and the changing era of industrialization, there are also new problems in it. These problems include depletion of employment opportunities, job opportunities with people looking for work, more people looking for work so that many people do not get the opportunity to work, as a result, the number of unemployed is getting bigger which has an impact on economic conditions in Indonesia. Most tertiary education graduates tend to choose to become job seekers rather than job creators. Developing entrepreneurship is solution to reduce high educated unemployment. The urgency to educate and train young people in entrepreneurship is proven to encouraging them to pursue entrepreneurial careers so that it can indirectly increase economic efficiency, bring innovation to markets, create new job opportunities, and maintain job levels [1].

The number of entrepreneurs in Indonesia, it is only $1.65 \%$ of the total population. When compared with the ratio of the population, Indonesia is very short on entrepreneurs. Indonesia must have at least $2 \%$ of entrepreneurs from the total population [2]. Many students are not interested in entrepreneurship to have their own business so they don't depend on their parents. Therefore, the university is an important agent for changing the future of the nation. The campus has an irreplaceable role in creating an entrepreneurial culture in Indonesia as well as forming and training new entrepreneurs. Universities are required to implement an entrepreneurship development curriculum and provide access and resources to foster student entrepreneurial intention, so that it is hoped that when students graduate students will be able to play a direct role in economic development through as a career choice to support welfare [3]. Universities provide knowledge and inspiration for student's entrepreneurship, so that there is a key role for education in developing entrepreneurial intentions. Professional education at University is an efficient way to acquire the entrepreneurial literacy needed to build an entrepreneurship business [18]. So that, the purpose of this study is to explores and tests the extent to which student's perceived university support can increase the impact of entrepreneurial literacy on student's intentions to become entrepreneurs.

\subsection{Social Cognitive Theory}

Social cognitive theory (SCT) by Albert Bandura is centred on the concept of reinforcement and observation, 
which emphasizes internal mental processes and the interaction of subjects with other people [4]. Social cognitive theory is used as a framework for this research because it recognizes that an individual's thinking and behaviour has a social context [5]. These thoughts and behaviours are influenced by a combination of direct observation and experience. Furthermore, SCT has been used as a framework for developing educational theories on how social learning affects student career intentions [6]. Turning to this research, integrating the perspective of the institutional level by conceptualizing student's perceptions of the support they receive from the institution, in this case, the university will increase student's entrepreneurial intentions supported by the entrepreneurial literacy that is obtained. Therefore, the purpose of this study is for research aimed at developing and testing a model of the relationship between entrepreneurship literacy, perceived university support and entrepreneurship intention of students in developing their business based on Social cognitive theory.

\subsection{Entrepreneurial intention}

Entrepreneurial intention is a tendency of person to be interested in create business then organizes, regulate, beat the risk, and develop their business [7]. Entrepreneurial intention facilitates the goals, commitment and communication needed to create their businesses. Entrepreneurial intention process involves three main activities which completed by a selection process. The processes are determining, creating, and maintaining. These three processes are structured and logical stages. A recent study revealed that entrepreneurial intentions are built on two main things, there are passion and creativity [8]. The spirit of entrepreneurship is a positive feeling that is consciously experienced when a person carries out entrepreneurial activities in a meaningful role, which confirms his identity as a business actor [9].

\subsection{Entrepreneurship literacy}

Entrepreneurial literacy is an important factor in an entrepreneurial activity because entrepreneurial literacy is the basis for being able to become an entrepreneur. For this reason, a person's entrepreneurial literacy can easily find out what things must be done when he decides to become an entrepreneur. Entrepreneurial literacy can be said to be very important for the formation of actions in a person. Entrepreneurial literacy is what is known about all forms of information that are processed in the cognitive realm in the form of memory and understanding of how to do business so that it creates the courage to take risks rationally and logically in handling any business. Therefore, an understanding of entrepreneurship is certainly important for students who have the intention to become entrepreneurs when they are determined to develop their success business [10].

H1: Entrepreneurship literacy has a positive effect on entrepreneurship intention.

\subsection{Perceived University Support}

Education is a benchmark that the higher a person's education level, the higher his entrepreneurial skills and entrepreneurial literacy. Individuals who feel that they lack entrepreneurial literacy, business risk, and financing are significantly less likely to have strong entrepreneurial intentions [11]. However, the fact is there is still a lack of student intention to build a business. A person's entrepreneurial literacy is insufficient, and more importantly not ready to take risks to realize their dreams. Educational and structural support factors can influence student entrepreneurial intention. If universities provide sufficient knowledge and inspiration for entrepreneurship, the likelihood of choosing an entrepreneurial career will increase among students [12].

Universities can support to identifying and developing entrepreneurial traits and tendencies among students and also enabling them to start their businesses, so it can effectively contribute to economic prosperity and job creation [13]. Therefore, the entrepreneurial support provided by universities is an efficient way of acquiring the necessary knowledge of entrepreneurship and motivates students to seek entrepreneurial careers [14]. In line with the previous statement which reveals that the role of universities can increase perceived entrepreneurial viability by increasing student entrepreneurial literacy, building trust, and promoting self-efficacy [15]. Thus, it can be formulated as follows.

H2: Perceived University Support has a positive and significant effect on entrepreneurship intention.

H3: Perceived University Support significant moderated Entrepreneurship literacy on entrepreneurship intention.

Based on the description above, a research model of the relationship between entrepreneurship literacy, perceived university support and entrepreneurship intention is developed in this study. The empirical research model that has been developed is as follows:

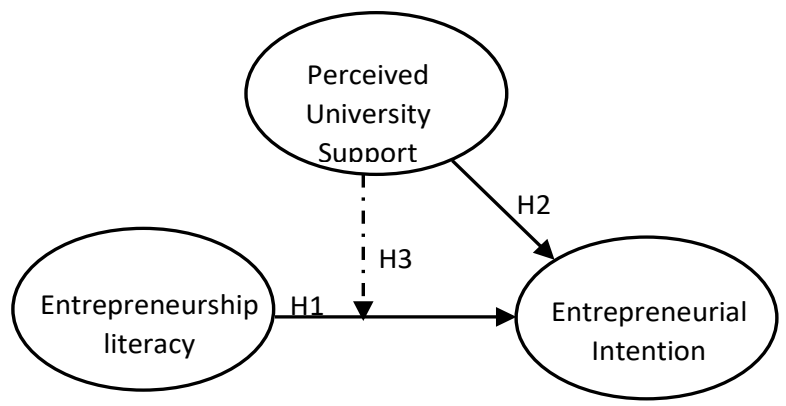

Figure 1. Empirical Research Model 
Table 1. Construct Validity and Reliability

\begin{tabular}{|c|c|c|c|c|}
\hline Variabel / Item & Loading Factor & AVE & Alpha Cronbach & Composite Reliability \\
\hline Enliter_1 sd Enliter_6 & 0.56 sd 0.83 & 0,68 & 0,84 & 0,88 \\
\hline PUC_1 sd PUC_6 & 0.58 sd 0.87 & 0,69 & 0,88 & 0,89 \\
\hline Intent_1 sd Intent_8 & 0.54 sd 0.88 & 0,74 & 0,78 & 0,93 \\
\hline
\end{tabular}

Note $:$ Eniter $=$ Entrepreneurship literacy; $\mathrm{PUC}=$ Perceived university support; Intent = Interpreneurship Intention

Table 2. Model Fit and Quality Indices

\begin{tabular}{|l|c|c|c|}
\hline \multicolumn{1}{|c|}{ Index } & Value & Cut of Value & Remarks \\
\hline Average path coefficient (APC) & $0.311, \mathrm{P}<0.001$ & $\mathrm{P}<0.05$ & Good \\
\hline Average R-squared (ARS) & $0.371, \mathrm{P}<0.001$ & $\mathrm{P}<0.05$ & Good \\
\hline Average adjusted R-squared (AARS) & $0.350, \mathrm{P}<0.001$ & $\mathrm{P}<0.05$ & Good \\
\hline Average block VIF (AVIF) & 1.024 & acceptable if $<=5$, ideally $<=3.3$ & Good \\
\hline Average full collinearity VIF (AFVIF) & 1.200 & acceptable if $<=5$, ideally $<=3.3$ & Large \\
\hline Tenenhaus GoF (GoF) & 0.423 & small $>=0.1$, medium $>=0.25$, large $>=0.36$ & Ideal \\
\hline Sympson's paradox ratio (SPR)=, & 1.000 & acceptable if $>=0.7$, ideally $=1$ & Ideal \\
\hline R-squared contribution ratio (RSCR) & 1.000 & acceptable if $>=0.9$, ideally $=1$ & Ideal \\
\hline Statistical suppression ratio (SSR) & 1.000 & acceptable if $>=0.7$, ideally $=1$ & Good \\
\hline $\begin{array}{l}\text { Nonlinear bivariate causality direction } \\
\text { ratio (NLBCDR) }\end{array}$ & 1.000 & acceptable if $>=0.7$ & \\
\hline
\end{tabular}

\section{METHOD}

An associative quantitative design was used in the study to test the hypothesis of the causality relationship between the analyzed variables through inferential statistical techniques, with the studentpreneur analysis unit who participated in the entrepreneurial community of HIPMI PT, (Association of Young Entrepreneurs for Indonesian College Students). The primary data of this study were obtained from a questionnaire survey with an agree disagree interval scale in a scale range of 1-5 with an extreme angle of strongly agree and strongly disagree, with a sampling technique according to Lemeshow to find the sample size with an unknown population with an error margin of 0.05 percent or the $\mathrm{Z}$ value of 1.96 as follows:

$$
n=\frac{\left(Z^{2} \cdot p \cdot(1-p)\right.}{d^{2}} \times 2
$$

So that the total sample size is 160 respondents. Measurement of each based variable is as follows.

a) Measurement of entrepreneurial intention is derived from entrepreneurial behaviour. In entrepreneurial intentions, it consists of five dimensions [16], five dimensions of entrepreneurial intention including: (a) Personal background; (b) Business knowledge; (c) Entrepreneurial motivation; (d) Auto entrepreneurial effectiveness; (e) Educational environment

b) Measurement of the entrepreneurial literacy variable indicator adopted according to previous research namely: 1) Taking business risks, 2) Analyzing business opportunities, 3) Formulating problem solutions [17].

c) Meanwhile, the indicators of Perceived University Support are measured by a scale rating of six indicator items [18].
To get a good result of the causality relationship test, to support it, a valid and reliable measurement model and structural model are needed, so the following steps are taken (1) pilot test, for reference in field testing; (2) then analyzed the validity and reliability of the constructs (3) then inferential statistical analysis with WARP PLS SEM; (4) report the results of the interim analysis [19].

\section{RESULTS}

After going through the pilot test, there were several improvements to the questionnaire items, and after another pilot test was carried out, all items showed valid and reliable results. These results can then be carried out for field testing which is then carried out further testing namely construct validity and construct reliability. The construct validity was tested on the convergent validity test and the discriminant validity test, while the construct reliability was tested based on Cronbach's alpha value and composite reliability while the test results on the outer model can be presented in the Table 2.

The outer model test results show that each item variable has met the criteria for convergent validity, that is each factor loading of each item is above the cut value above 0.5. This is also in line with the results of discriminant validity, which can be seen from the Average Variance Extracted (AVE) value above the cut value of 0.5 . Meanwhile, the reliability of the research consisting of alpha Cronbach-based and composite reliability was above 0.7 , so it can be concluded that all variables are reliable. 
Then proceed to the inner model test and hypothesis testing (goodness of fit test and $\mathrm{t} /$ hypothesis test). For this reason, this test is based on several test indices for the fit and quality model, which in this study consists of
The findings also show that perceived university support is empirically proven to have a positive and significant effect on entrepreneurial intention, and perceived university support significantly moderates the

Table 3. Hypothesis Testing

\begin{tabular}{|c|c|c|c|c|}
\hline Hypothesis & Coefficient & Standar error & p-value & Description \\
\hline $\mathrm{H}_{1}:$ Entrepreneurship Literacy $\rightarrow$ Intrapreneurial Intention & 0.363 & 0.078 & 0.005 & Supported \\
\hline $\mathrm{H}_{2}:$ Perceived University Support $\rightarrow$ Intrapreneurial Intention, & 0.356 & 0.072 & 0.001 & Supported \\
\hline $\begin{array}{l}\mathrm{H}_{3} \text { : Entrepreneurship Literacy } * \text { Perceived University Support } \rightarrow \\
\text { Intrapreneurial Intention }\end{array}$ & 0.391 & 0.079 & 0.001 & Supported \\
\hline
\end{tabular}

several indexes, namely the average path coefficient (APC), average R-squared (ARS), average adjusted Rsquared (AARS), average block VIF. (AVIF), average full collinearity VIF (AFVIF), tenenhaus GoF (GoF), sympson's paradox ratio (SPR), R-squared contribution ratio (RSCR), statistical suppression ratio (SSR), nonlinear bivariate causality direction ratio (NLBCDR). The results of the goodness of fit are as follows:

Based on the results of the inner model test with the WARP PLS SEM technique, it can be seen that all of the goodness of fit test criteria, from the average path coefficient (APC) to the nonlinear bivariate causality direction ratio (NLBCDR), meet good or ideal criteria. So that the evaluation or test on the inner model meets the WARP PLS SEM criteria well, then it can be continued in hypothesis testing. The hypothesis test results can be shown in the following table:

The results of all hypothesis tests show that both hypotheses 1, 2 and 3 are all statistically significant, as indicated by the overall p-value of the three above 0.05 . This means that entrepreneurial literacy has a positive and significant impact on increasing entrepreneurial intention, while perceived university support besides having a positive and significant impact on entrepreneurial intention, this variable also significantly moderates the effect of entrepreneurial literacy on entrepreneurial intention.

\section{DISCUSSION}

Entrepreneurial literacy is proven have a positive and statistically significant effect on entrepreneurial intention. This is shows that the increase in entrepreneurial literacy is directly proportional to entrepreneurial intention. It happens because intention is a form of entrepreneurial spirit as positive feeling that is consciously experienced when someone have entrepreneurial activities. This will certainly be awakened if the university provides adequate knowledge and inspiration for entrepreneurship, the possibility of choosing an entrepreneurial career will increase among students [18]. The results of this study confirm the key role of education in the development of entrepreneurial intentions. In line with previous research show that university professional education is an efficient way to obtain entrepreneurial literacy which can build entrepreneurial intentions for many students [21]. impact of entrepreneurial literacy on entrepreneurial intention. This shows that encouragement from the university environment affects student entrepreneurial beliefs. Since the education offered by universities greatly influences student career choices, universities can be seen as a potential source for future entrepreneurs. In line with the findings of this study, confirmed that the strength of entrepreneurial intentions is driven by the education offered by universities [16]. In the research findings, also showed that the support of the university environment is a significant predictor of entrepreneurial intentions [20]. Educational support which indicates a particularly supportive university environment. This shows that the key role of education in developing entrepreneurial intentions. Support from universities is expected to at least encourage the development of creative ideas to become an entrepreneur, provide the necessary knowledge about entrepreneurship, and develop student entrepreneurial skills. Therefore, universities may have an important role in encouraging students to choose their entrepreneurial careers [21].

\section{CONCLUSION}

This research has shown that support from the university is very important in encouraging the intention to become entrepreneurs. University support in providing an environment such as an entrepreneurial community (HIPMI PT) is a step to encourage the influence of entrepreneurial literacy apart from entrepreneurship learning that is obtained by students through the classroom. Therefore, university support in the form of policies or strengthening other curricula can support student's desire to become entrepreneurs or establish start-ups, the need for student business incubators to be carried out seriously to support entrepreneurial outcomes, namely the creation of many start-up businesses established by students. Even though this research is limited in measuring the scope of the university and student internal factors, future research is expected to add to the variables from other external factors.

\section{AUTHORS' CONTRIBUTIONS}

Ririn Alfianti had contributed in reviewing literature deeply, and Kemal Budi Mulyono and Firda Nurhidayati had contributed in analyzing data.. 


\section{ACKNOWLEDGMENTS}

Thanks for Faculty of Economics Universitas Negeri Semarang had supported funding in this research.

\section{REFERENCES}

[1] M. Carswell and D. Rae, "Towards a conceptual understanding of entrepreneurial learning", Journal of Small Business and Enterprise Development 8 (2), 2001, pp. 150-8, DOI: https://doi.org/10.1108/EUM0000000006816

[2] Bank Indonesia, Bank Indonesia official website Bank Sentral Republik Indonesia, 21 Nopember 2014. from: https://www.bi.go.id/id/. [Retrieved September 30, 2020]

[3] E.N. Lince, "Entrepreneurship skills Need to be Created". Kompas, 11 July 2011. from: https://kompas.com [Retrieved 3 November 2020. 2011].

[4] C.E. Bayrón, "Social Cognitive Theory, Entrepreneurial Self-Efficacy and Entrepreneurial Intentions: Tools to Maximize the Effectiveness of Formal Entrepreneurship Education and Address the Decline in Entrepreneurial Activity", Griot Magazine, 6 (1), 2016, pp. 66-77.

[5] A. Bandura, "Organizational Applications of Social Cognitive Theory", Australian Journal of Management, 13, 1986, pp. 275-302.

[6] A. Bandura, Social Learning Theory. Prentice-Hall, Inc, New Jersey, 1977.

[7] B. Bird, "Implementing Entrepreneurial Ideas: The Case for Intention", The Academy of Management Review, 13(3), 1988, pp. 442-453. DOI: https://doi.org/10.2307/ 258091

[8] A. Biraglia, and V. Kadile, "The Role of Entrepreneurial Passion and Creativity in Developing Entrepreneurial Intentions: Insights from American Homebrewers", Journal of Small Business Management, 55(1), 2017, pp. 170-188. DOI: https://doi.org/10.1111/jsbm. 12242

[9] M.S. Cardon and C.P. Kirk, "Entrepreneurial Passion as Mediator of The Self-Efficacy to Persistence Relationship". Entrepreneurship Theory and Practice, 39(5), 2015, pp. 1027-1050. DOI: https://doi.org/10.1111/etap.1208

[10] Abdullah, A. Aziz, N.N Sulaiman, "Factors That Influence the Interest of Youths in Agricultural Entrepreneurship", International Journal of Business and Social Science 4 (3), 2013.

[11] Pruett, Mark \& Shinnar, Rachel \& Toney, Bryan \& Lopis, Francisco \& Fox, Jerry, "Explaining Entrepreneurial Intentions of University Students: a Cross-cultural Study", International Journal of Entrepreneurial Behaviour \& Research, 2009. DOI: https://doi.org/15.571594.10.1108/1355255091099 5443.

[12] D. Turker, "Which Factors Affect Entrepreneurial Intention of University Students?", 2008. DOI: https://doi.org/10.1108/03090590910939049

[13] K. Debackere and R. Veugelers, "The Role of Academic Technology Transfer Organization in Improving Industry Science Links", Research Police 34(3), 2005, pp. 321-342. DOI: https://doi.org/10.1016/j.respol.2004.12.003

[14] R. Henderson and M. Robertson, "Who Wants to be an Entrepreneur? Young Adult Attitudes to Entrepreneurship as a Career", Education + Training 41 (5), 1999, pp. 236-245. DOI: https://doi.org/10.1108/0040091991027997

[15] N.F. Krueger and D.V. Brazeal, "Entrepreneurial Potential and Potential Entrepreneurs". Entrepreneurship Theory and Practice 18(3), 1994, pp. 91-104. DOI: https://doi.org/10.1177/104225879401800307

[16] E. Autio, R.H. Keeley, M. Klofsten, and Ulfstedt. "Entrepreneurial Intent Among Students: Testing an intents Model in Asia, Scandinavia and USA", Frontiers of Entrepreneurship Research, Babson Conference Proceedings. Retrieved from https://www.babson.edu/, 1997.

[17] M.A. Mustofa, "The Influence of Entrepreneurial Literacy, Self and Entrepreneurial Character on Entrepreneurial Intention of Students Class XI SMK N 1 Depok Sleman, Thesis, Yogyakarta: UNY, 2014.

[18] J. Kraaijenbrink, A. Groen, and G. Bos, "What Do Students Think of the Entrepreneurial Support Given by Their Universities?", International Journal of Entrepreneurship and Small Business 9 (1), 2010, pp. 110-125.

[19] I. Ghozali, and H. Latan, "Partial Least Square Concepts, Techniques and Application Using WarpPLS 4.0", Semarang: Diponegoro University Publishing Agency, 2014.

[19] C.K. Wang and P. Wong, "Entrepreneurial Interest of University Students in Singapore", Technovation 24 (2), 2004, pp. 163-172. DOI: https://doi.org/10.1016/s0166-4972(02)00016-0

[20] C. Lüthje and N. Franke, "The Making of an Enrepreneur Testing a Model of Entrepreneurial Intent among Engineering Students at MIT", R\&D Management, 33(2), 2003.

[21] S. Saeed, S. Yousafzai, Yani-de-Soriano, and M. Muffatto, "The Role of Perceived University Support in the Formation of Student's Entrepreneurial Intention", Sustainable Entrepreneurship, 2018, pp. 3-23. DOI: https://doi.org/10.4324/9781315611495-1 